\title{
PENDAMPINGAN PASTORAL TERHADAP PENYESUAIAN DIRI MAHASISWA IAKN KUPANG DALAM MENGHADAPI PANDEMI COVID-19
}

\author{
Dr. Anggreani N. Paat, M.Si \\ IAKN Kupang \\ anggreanipaat@yahoo.co.id
}

\begin{abstract}
At the beginning of 2020, the people in the world were shocked by the outbreak of a new type of virus, namely Coronavirus disease 2019 (COVID-19). The impact of this virus outbreak is felt by the world of education. Such conditions interfere with the achievement of student maturity in achieving their learning goals, namely from an academic, psychological and spiritual perspective. This impact was also experienced by students of the Kupang State Christian Institute (IAKN). The purpose of the study was to find out empirically about pastoral assistance for adjustment to IAKN Kupang students in the face of the Covid-19 pandemic and to find out how big the role of pastoralism is in adjustment. This study used a qualitative method by taking the subject of 10 students of IAKN Kupang. The ten students were quite capable of adjusting to the Covid 19 pandemic. This cannot be separated from the role of parents, campuses, churches and government as companions. Assistance provided by people around the students in the form of advice and suggestions for healthy living, adhering to health protocols, and staying enthusiastic in undergoing online lectures. Parents and companions can act as helpers and listeners for students during the Covid-19 pandemic
\end{abstract}

\begin{abstract}
ABSTRAK
Pada awal tahun 2020, masyrakat di dunia dihebohkan dengan merebaknya jenis virus baru yaitu Coronavirus disease 2019 (COVID-19). Dampak mewabahnya virus ini dirasakan oleh dunia pendidikan. Kondisi demikian mengganggu pencapaian kematangan mahasiswa dalam meraih tujuan belajarnya yaitu dari segi akademis, psikologis, dan spiritualitas. Dampak tersebut juga dialami mahasiswa Institut Agama Kristen Negeri (IAKN) Kupang. Tujuan dari penelitian adalah untuk mengetahui secara empirik mengenai pendampingan pastoral terhadap penyesuaian diri pada mahasiswa IAKN Kupang dalam menghadapi pandemi Covid-19 serta untuk mengetahui seberapa besar peran pastoral terhadap penyesuaian diri. Penelitian ini menggunakan metode kualitatif dengan mengambil subyek 10 orang mahasiswa IAKN Kupang. Kesepuluh mahasiswa cukup mampu menyesuaikan diri terhadap pandemi Covid 19. Hal tersebut tidaklah lepas dari peran orangtua, kampus, gereja, dan pemerintahan sebagai pendamping. Pendampingan yang diberikan orang-orang yang ada disekitar mahasiswa berupa nasihat dan saran untuk hidup sehat, mematuhi protokol kesehatan, dan tetap bersemangat dalam menjalani perkuliahan online. Orangtua dan pendamping dapat sebagai seorang penolong dan pendengar bagi mahasiswa di masa pandemi Covid-19.
\end{abstract}

Kata Kunci : Covid 19, Penyesuaian diri, Pendampingan Pastoral 


\section{PENDAHULUAN}

Pada awal tahun 2020, dunia dihebohkan dengan merebaknya jenis virus Severe acute respiratory syndrome corona virus-2 (SARS-CoV-2) dan nama penyakitnya adalah Coronavirus disease 2019 (COVID-19). Di kota Wuhan Tiongkok tahun 2020 pertama kali virus ini ditemukan. Proses penyebaran virus corona tergolong cepat, karena dapat melalui interaksi antara manusia dengan manusia. Menurut data yang dilansir WHO bulan April 2020, saat ini sudah dipastikan bahwa 65 negara telah terinfeksi virus tersebut. Berdasarkan data tanggal 20 April 2020, jumlah kasus Covid-19 di dunia adalah sebanyak 2.394.291 orang terinfeksi (2,39 juta). Dari data tersebut, 164.938 orang dilaporkan meninggal dunia, dan 611.880 pasien dinyatakan sembuh dari virus ini.

Salah satu negara berkembang yang ikut terpapar adalah Indonesia. Dari data yang terkonfirmasi Total kasus Covid-19 di bulan April adalah sebanyak 9.511 kasus. Sedangkan angka kematian yang terjadi adalah sebanyak 773 kasus (Kemenkes RI, 2020). Tingginya jumlah penderita Covid-19 di Indonesia membuat Pemerintah Indonesia mengambil langkah cepat untuk menekan penyebaran virus Covid-19 dengan melakukan social distancing kepada masyarakat dimana kebijakan ini diharapkan akan meminimalisir penyebaran Covid-19.

Pada tanggal 15 Maret 2020 secara resmi Presiden Joko Widodo mengeluarkan himbauan agar seluruh instansi negeri dan swasta menghindari kerumuman manusia seperti kegiatan bekerja, belajar, dan beribadah dari rumah. Hal ini dimaksudkan agar penyebaran virus Covid-19 tersebut dapat dibatasi serta masyarakat walau sedang di rumah juga tetap produktif dalam bekerja maupun belajar. Selain itu juga untuk menghindari kontak langsung dengan orang lain yang sudah terinfeksi.

Kebijakan Presiden kemudian ditindaklajuti oleh beberapa pemerintah di daerah dengan mulai mengeluarkan beberapa kebijakan seperti belajar dari rumah selama masa pandemi Covid19 hingga akhir Mei 2020, kemudian adanya pembatasan kegiatan yang melibatkan orang ramai bahkan dihapuskan. Selain itu instansi pemerintah maupun swasta mengeluarkan kebijakan work from home (WFH) dengan adanya berbagai kriteria-kriteria tertentu.

Pemberlakuan social distancing dan WFH juga dirasakan oleh masyarakat Kota Kupang, Nusa Tenggara Timur. Terlebih lagi sebanyak 813 orang dinyatakan sebagai orang dalam pemantauan (ODP) dan satu orang dinyatakan positif mengidap Covid-19. Berbagai sektor di Kota Kupang khususnya perekonomian, kesehatan dan pendidikan menjadi persoalan yang sedang urgent untuk diperhatikan. Jumlah ODP yang mulai meningkat di Kota Kupang, membuat pemerintah lebih sigap dengan menyediakan layanan kesehatan berupa empat rumah sakit di Kota Kupang yang ditunjuk menjadi rumah sakit second line (Pemkot Kupang, 2020). Pemerintah Kota Kupang juga menyediakan pengadaan alat perlindungan diri (APD) bagi para tenaga medis di rumah sakit second line tersebut.

Dunia pendidikan juga merasakan dampak dari virus corona (Covid-19). Hal ini telah diakui oleh organisasi Pendidikan, Keilmuan, dan Kebudayaan Perserikatan Bangsa-Bangsa (UNESCO). Sekitar 300 juta pelajar terganggu kegiatan belajarnya di seluruh dunia hingga terancam hak pendidikannya di masa depan. Hal yang paling dikhawatirkan adalah efek jangka panjang dari penyebaran virus ini. Para pelajar dan mahasiswa secara otomatis akan merasakan keterlambatan dalam proses pendidikan yang akan dijalani. Dengan kebijakan belajar secara mandiri di rumah bebarapa negara yang terdampak virus secara otomatis dapat mengganggu hak setiap warganya untuk mendapatkan layanan pendidikan. 


\section{Bagaimana dengan Mahasiswa IAKN kupang?}

Sebagai tenaga pendidik dan juga pelajar dituntut harus beradaptasi dengan keadaan ini, terutama proses pembelajaran akan menggunakan media online. Perubahan proses pembelajaran yang drastis ini tentunya dibutuhkan kesiapan secara mental antara tenaga pendidik dan pelajar untuk menghadapinya. Salah satu dampak tersebut dialami mahasiswa Institut Agama Kristen Negeri (IAKN) Kupang.

Institut Agama Kristen Negeri (IAKN) Kupang merupakan lembaga pendidikan kristen yang terdepan di wilayah Nusa Tenggara. Terlebih lagi jumlah masyarakat yang beragama Kristen lebih mendominasi. Merupakan suatu tanggung jawab besar ke depan, bukan hanya soal toleransi dan kerukunan semata tetapi masalah mendasar yang ada di Nusa Tenggara Timur yaitu kemiskinan. Bila dilihat, antusiasme masyarakat untuk menempuh pendidikan di perguruan tinggi cukup tinggi. Akan tetapi terkendala biaya pendidikan yang masih dianggap mahal bagi masyarakat yang berlatar berlatar belakang menengah ke bawah. Oleh karena itu, masyarakat menginginkan adanya jurusan yang bervariasi dengan biaya pendidikan yang terjangkau. IAKN Kupang memiliki 3 jurusan yang diminati oleh masyarakat yaitu Pendidikan Agama Kristen (PAK), Pastoral Konseling, dan Musik Gerejawi.

Mahasiswa IAKN Kupang yang mayoritas orangtuanya berprofesi sebagai petani dan pedagang sangat merasakan dampak dari penyebaran Covid-19. Orangtua mahasiswa yang sebagian besar berdomisili di daratan tanah Timor seperti kota Soe, Kefa, dan Atambua mengalami keresahan karena minimnya pemasukan yang diterima. Kurangnya uang yang dikirimkan oleh orangtua menjadi alasan kuat mahasiswa tidak siap untuk menerima proses pembelajaran secara online. Mahasiswa beralasan tidak mampu untuk membeli paket internet untuk dapat mengikuti proses pembelajaran. Selain itu dampak yang sangat terasa karena minimnya uang yang dikirimkan orangtua adalah kurangnya pasokan bahan pangan untuk memenuhi kebutuhan sehari-hari. Perubahan yang terjadi mulai memunculkan berbagai respon secara verbal dan tingkah laku pada mahasiswa, seperti mengeluh ketika diberikan tugas secara online, merasa terabaikan oleh orangtua, dan perasaan frustasi memikirkan kebutuhan pokok tiap harinya.

Perubahan yang dialami tentunya dirasakan berat, terlebih bagi mahsiswa yang sedang beranjak ke dewasa, awal tentunya masih perlu dukungan dan arahan. Tahap perkembangan diri mahasiswa dikategorikan dari usia 18-25 tahun (Papalia, 2008). Sebagai seorang remaja akhir yang menuju dewasa awal tentunya butuh banyak penyesuaian diri dengan perubahan yang mendadak terjadi. Hurlock (2004) menayatakan bahwa tugas perkembangan mahasiswa yang sulit dicapai yaitu penyesuaian diri. Penyesuaian diri menurut Schneiders (dalam Ali \& Asrori, 2012) adalah usaha individu untuk mengatasi kebutuhan, ketegangan, konflik dan frustrasi yang dialami didalam dirinya. Keberhasilan dari proses penyesuaian diri adalah dengan memperoleh keselarasan dan keharmonisan antara tuntutan dalam diri dengan apa yang diharapkan oleh lingkungan sekitar.

Hasil observasi awal terdapat beberapa mahasiswa usia 18-25 tahun yang mengalami kesulitan dalam penyesuaian dirinya terhadap penyebaran Covid-19 saat ini. Mahasiswa kurang dapat menampilkan diri secara nyata, tidak mampu menyesuaikan diri dengan berbagai keadaan yang mendesak, tidak mampu berinteraksi sosial di masyarakat, tidak bisa menerima keadaan diri. Salah satu hal yang paling nyata adalah kurang mampu menyesuaikan diri dengan pembelajaran online. Mahasiswa pun mulai merasakan ketidaksejahteraan dalam kehidupan sehari-hari karena kurang tersedianya pangan.

Menurut Andriyani (2016) kegagalan tersebut karena adanya masalah keluarga. Masalah keluarga yang sering terjadi adalah seperti status ekonomi orang tua yang menengah ke bawah, orang tua yang sangat sibuk bekerja sehingga tidak perhatian pada anak. Dampaknya menyebabkan anak kurang memiliki harga diri dan kurang dapat bergaul dengan teman, serta mengalami kendala 
saat penyesuaian diri dengan teman yang status ekonomi orang tuanya menengah ke atas. Status ekonomi orangtua mahasiswa IAKN Kupang yang menurun akibat dari Covid-19 membuat mahasiswa merasa bahwa orangtua kurang mempedulikan mereka. Perasaan kurang dipedulikan tersebutlah yang memunculkan perasaan mulai tidak percaya diri sehingga menarik diri dari lingkungan.

Beberapa faktor yang mempengaruhi penyesuaian diri mahasiswa seperti keadaan fisik, kematangan dan perkembangan, keadaan psikologis, lingkungan, dan agama dan budaya. Tindak acuh tidak mau mengikuti perkuliahan online, memprotes tenaga pendidik karena diberikan tugas, menarik diri dari kelompok, merasa diabaikan orangtua dan keluarga adalah beberapa contoh dari kegagalan penyesuaian diri terhadap tekanan dan frustasi yang dialami dari lingkungan. Perubahan yang dialami oleh seseorang dalam lingkungannya akan menjadi sumber stres. Individu dituntut untuk menyesuaikan diri sehingga terjalin keharmonisan antara kebutuhan dirinya dan tuntutan lingkungan (Andriyani, 2016). Keadaan lingkungan saat inilah yang menuntut mahasiswa IAKN Kupang untuk mampu beradaptasi terhadap perkuliahan online. Selain itu kurang siapnya mahasiswa secara psikologis menghadapi kenyataan bahwa minimnya pemasukan keuangan orangtua yang berdampak pada kehidupan keseharian mereka.

Selain faktor keuangan, penyesuaian diri yang harus dialami mahasiswa adalah dari segi spiritualitas. Mahasiswa harus beradaptasi dengan perubahan tata ibadah. Perubahan tersebut seperti melakukan ibadah secara online di rumah. Ibadah secara online di rumah merupakan salah satu langkah pemerintah dalam menerapkan social distancing, agar menekan jumlah penderita Covid-19. Akan tetapi, keterbatasan ekonomi mahasiswa untuk membeli pulsa pun menjadi penyebab mahasiswa tidak dapat melakukan ibadah secara online. Perubahan dalam tata ibadah menjadi sebuah penyesuaian baru lagi yang harus dilalui oleh mahasiswa.

Permasalahan yang dihadapi mahasiswa ini memunculkan kompleksitas masalah dalam kehidupan sehari-hari. Baik permasalahan dengan diri sendiri, orang lain maupun dengan lingkungannya. Setiap permasalahan memerlukan solusi, baik melalui diri sendiri, maupun pendampingan dari orang lain. Pendampingan dari orang lain dapat membantu menguraikan kompleksitas permasalahan di dalam kehidupannya. Adapun permasalahan yang sedang dialami mahasiswa sendiri mempunyai empat aspek yang mempengaruhi kehidupannya, yaitu fisik, mental, sosial, dan spiritual.

Keempat aspek tersebut sangat berpengaruh dalam permasalahan hidup mahasiswa. Menghadapi kenyataan tersebut, salah satu faktor yang dapat mendukung keadaan mahasiswa agar mampu melakukan penyesuaian diri terhadap keadaan yang terjadi adalah pendampingan pastoral. Pendampingan pastoral merupakan sebuah upaya dalam rangka menolong sesama manusia yang mengalami berbagai permasalahan hidup (Nugroho, 2017).

Istilah pastor berasal dari bahasa Latin artinya gembala (Bons, 2012). Gembala adalah seseorang yang memiliki sifat-sifat khas antara lain bersedia merawat, membimbing, melindungi dan menolong orang lain seperti Kristus yang adalah gembala agung dalam Gereja. Tujuan dari pendampingan pastoral yaitu mendampingi individu dari segi spiritual dalam proses penyesuaian diri secara utuh (holistik). Kebutuhan holistik seperti fisik yaitu istirahat, mengkonsumsi obat dan vitamin, kebutuhan jiwa seperti membutuhkan dukungan dalam menghadapi masalah, kebutuhan sosial seperti bercerita dan mengobrol, dan rohani seperti hubungan yang baik dengan sang Pencipta.

Pendampingan pastoral diharapkan dapat mendukung proses penyesuaian diri mahasiswa dalam menghadapi dampak Covid-19 ini. Schaneiders mengatakan bahwa individu yang dapat menyesuaikan diri dengan baik adalah individu yang mau belajar untuk bereaksi terhadap dirinya dan lingkungan dengan cara yang matang, efesien, dan dapat menyelesaikan konflik. Oleh sebab itu diharapkan bahwa pendampingan pastoral dapat mendukung penyesusain diri pada mahasiswa. 
Penelitian ini bertujuan untuk mengetahui mengenai pendampingan pastoral terhadap penyesuaian diri pada mahasiswa IAKN Kupang dalam menghadapi pandemi Covid-19 serta untuk mengetahui seberapa besar sumbangan efektif pastoral terhadap penyesuaian diri.

\section{Pengertian Penyesuaian Diri}

Penyesuaian diri adalah usaha manusia di lingkungannya untuk mencapai suatu harmonisasi pada diri sendiri (Kartono, 2000). Sedangkan menurut Fatimah (2006) penyesuaian diri adalah proses yang ditempuh individu untuk mencapai keseimbangan sehingga dapat memenuhi kebutuhannya sesuai dengan tuntutan lingkungan. Menurut Prof Sunarto dan Agung Hartono (2013), penyesuaian diri dapat di artikan atau dideskripsikan sebagai berikut:

a. Penyesuaian dapat berarti adaptasi untuk mempertahankan eksistensinya, sehingga dapat memperoleh kesejahteraan jasmaniah dan rohaniah.

b. Penyesuaian juga sebagai konformitas untuk menyesuaikan sesuatu dengan standar atau prinsip.

c. Penyesuaian adalah penguasaan untuk mencapai kematangan emosional yang tepat pada setiap situasi.

Dengan demikian, dapat dikatakan bahwa penyesuaian diri merupakan proses untuk mengubah perilaku pada individu agar terjadi relasi yang lebih sesuai antara diri sendiri, orang lain dengan lingkungannya. Berarti kemampuan manusia sanggup untuk membuat relasi yang menyenangkan antara individu dengan lingkungannya.

\section{Aspek Penyesuaian Diri}

Dua aspek Penyesuaian diri (Buchori, 2002) yaitu:

a. Penyesuaian Pribadi.

Kemampuan individu untuk menerima diri sehingga terjadinya hubungan harmonis antara diri sendiri dan lingkungannya. Penyesuaian diri pribadi memahami kelebihan dan kekurangan diri sehingga mampu bertindak secara obyektif sesuai dengan kondisi dirinya. Keberhasilan dari penyesuaian diri pribadi adalah kurangnya rasa benci, lari dari masalah, dan berusaha bertanggung jawab dengan diri sendiri. Sebaliknya, kegagalan penyesuaian pribadi ditandai dengan cepat emosi, selalu merasa cemas, adanya ketidakpuasan, dan keluhan terhadap masalah yang dialami.

b. Penyesuaian Sosial

Ruang lingkup penyesuaian sosial dapat terjadi dimana individu beriteraksi dengan orang lain dan hubungan dirinya dengan masyarakat sekitar. Setiap individu dapat 
saling memengaruhi satu sama lain yang mempunyai aturan, hukum, adat, dan nilai-nilai yang dipatuhi. Dalam penyesuaian sosial, individu dituntut mematuhi norma dan peraturan sosial di masyarakat.

\section{Karakteristik Penyesuaian Diri}

Hurlock (2004) menyatakan bahwa penyesuaian diri memiliki beberapa karakterisik yaitu : a. Penampilan nyata melalui sikap dan tingkah laku sehar-hari

Bentuk dari penampilan nyata adalah aktualisasi diri dan mengembangkan potensi diri, keterampilan menjalin hubungan seperti berkomunikasi, kemampuan berorganisasi, dan kesediaan untuk terbuka pada orang lain.

b. Penyesuaian Diri terhadap Berbagai Kelompok

Bentuk dari penyesuaian diri seperti bekerja sama dengan kelompok yaitu proses beregu dimana anggota-anggotanya mendukung dan saling mengandalkan untuk mencapai suatu hasil, adanya tanggung jawab yaitu sesuatu yang harus kita kerjakan agar kita menerima hak, dan adnaya sikap solidaritas yaitu saling menolong dan memotivasi.

c. Sikap Sosial

Adanya partisipasi sosial terhadap perannya dalam kelompok maka individu berusaha menyesuaikan diri secara sosial. Bentuk dari sikap sosial adalah ikut berpartisipasi dalam kegiatan sosial di masyarakat, sikap berempati, dan tenggang rasa dengan pendapat orang lain.

d. Kepuasan Pribadi

Individu harus merasa puas terhadap kontak sosialnya dan terhadap peran yang yang dimainkannya dalam situasi sosial. Bentuk dari kepuasan pribadi yaitu rasa percaya diri, kedisiplinan dan kehidupan yang terarah.

\section{Faktor-Faktor Yang Mempengaruhi Proses Penyesuaian Diri}

Ada tiga (3) faktor yang memengaruhi penyesuaian diri pada diri remaja (Fatimah, 2006) adalah :

a. Lingkungan Keluarga yang Harmonis

Perasaan cinta, kasih, respek, kehangatan dapat menciptakan keluarga yang harmonis. Hal ini sangat memengaruhi proses penyesuaian diri pada remaja. Kelekatan remaja pada keluarga yang harmonis merupakan salah satu faktor penting yang menunjuang penyesuaian dirinya.

b. Lingkungan Teman Sebaya

Remaja menggunakan teman sebayanya untuk proses pengembangan jati dirinya. Sebab teman sebaya merupakan lingkungan pertumbuhan dan perkembangan yang sangat dekat dengan remaja. Remaja akan mencurahkan kepada teman apa yang tersimpan di dalam hati dan pikirannya.

c. Lingkungan Sekolah

Lingkungan sekolah peran dan tanggung jawab secara moral dan sosial bagi penyesuaian diri remaha. Peran guru tidak hanya mengajar tetapi juga berperan sebagai pendidik, pembimbing dan pelatih bagi siswanya.

\section{Karaktaristik Perkembangan Mahasiswa}

Adanya transisi dari bangku sekolah menangah atas (SMA) menuju perkuliahan menimbulkan stres. Transisi ini melibatkan gerakan menuju satu struktur pendidikan yang lebih 
besar dan tidak bersifat pribadi, seperti interaksi dengan kelompok sebaya dari daerah yang lebih beragam dan peningkatan perhatian pada prestasi dan penilaiannya (Santrock, 2002). Perguruan Tinggi dapat menjadi tempat peningkatan intelektual dan pertumbuhan kepribadian diri mahasiswa.

Pada saat di perkuliahan adanya pandangan dan nilai yang berbeda antar mahasiswa, baik secara kultur, kebiasaan, dan norma yang dianut. Oleh karena itu pilihan perguruan tinggi dapat mewakili pengejaran terhadap hasrat yang menggebu atau awal dari karir masa depan (Papalia dkk, 2008). Ciri-ciri perkembangan remaja akhir (usia 18-21 tahun) dapat dilihat dalam tugas-tugas perkembangan (Gunarsa, 2001) yaitu:

a. Menerima keadaan fisik

Perubahan fisiologis seperti struktur dan penampilan fisik yang sudah menetap dan harus diterima sebagaimana adanya.

b. Memperoleh kebebasan emosional

Masa remaja akhir ada pada proses melepaskan diri dari ketergantungan secara emosional dari orang yang dekat dalam hidupnya seperti orangtua. Kebebasan emosional mampu mengungkapkan pendapat dan perasaannya dengan sikap yang sesuai dengan lingkungan.

c. Mampu bergaul

Remaja mampu menyesuaikan dan memperlihatkan kemampuan sosialisasi dalam tingkat kematangan sesuai dengan norma sosial yang ada. Remaja mengembangkan kemampuan mengadakan hubungan sosial dengan teman sebaya maupun orang lain yang berbeda tingkat kematangan sosialnya.

d. Menemukan model untuk identifikasi

Proses mengarah pada kematangan pribadi, dimana tokoh identifikasi sering menjadi faktor penting. Tokoh identifikasi timbul akan menjadi model yang dapat ditiru sehingga memberikan pengarahan bagaimana bertingkah laku dan bersikap yang tepat.

e. Mengetahui dan menerima kemampuan sendiri

Pengertian dan penilaian yang objektif mengenai keadaan diri sendiri mulai ditanamkan. Kekurangan dan kegagalan yang bersumber pada keadaan kemampuan tidak lagi mengganggu berfungsinya kepribadian dan menghambat prestasi yang ingin dicapai.

f. Memperkuat penguasaan diri atas dasar skala nilai dan norma

Nilai pribadi yang menjadi norma dalam melakukan sesuatu tindakan bergeser ke arah penyesuaian terhadap norma yang berbeda dari dirinya. Baik yang berhubungan dengan nilai sosial ataupun nilai moral.

g. Meninggalkan reaksi dan cara penyesuaian kekanak-kanakan

Dunia remaja mulai ditinggalkan dan dihadapannya terbentang dunia dewasa yang akan dimasuki. Ketergantungan secara psikis mulai ditinggalkan dan ia mampu mengurus dan menentukan sendiri.

\section{Pendampingan Pastoral}

Pendampingan adalah kegiatan mendampingi yang dilakukan seorang pendamping terhadap orang lain yang sedang dalam masalah. Dalam hal ini kedudukan mereka sejajar (Bebek, 2014). Pendampingan adalah saling tolong menolong, menemani, berbagi, menemani dengan tujuan saling menyatu. Segala kelebihan yang ada pada pendamping harus dipakai untuk menumbuhkan relasi yang sejajar.

Seorang pendamping memfokuskan perhatian pada manusia secara utuh atau holistik. Perhatian seorang pendamping pada masalah dan kebutuhan manusia secara menyeluruh baik aspek fisik, emosi, sosial dan rohani. Lewat pendampingan, seseorang dipulihkan secara holistik. 
Pastoral adalah kata Latin Pastor yang berarti gembala ( Abineno: 2010). Menurut Bons (2012) pastor berasal dari kata Yunani Poimen yang artinya gembala. Sifat gembala yang dimaksud adalah perilaku seseorang yang bersifat pastoral. Seseorang dikatakan memiliki sifat seorang gembala apabila ia bersedia merawat, memelihara, melindungi dan menolong orang lain dalam hidupnya. Hal ini diungkapkan oleh Tuhan Yesus sebagai gembala yang Agung dalam Yohanes pasal 10.

Bons (2012) menguraikan yang disebut gembala dalam jemaat adalah: Tuhan Yesus, pendeta, para pelayan gereja dan jemaat. Mereka diharapkan menjalankan tugas pendampingan Pastoral. Tugas pastoral adalah tindakan seseorang yang bersedia merawat, memperhatikan, memelihara dan melindungi seseorang.

Menurut Beek (2015), ada 6 fungsi Penggembalaan antara lain:

a. Fungsi membimbing. Ada saat seseorang ragu untuk mengambil keputusan yang tepat maka ia perlu didampingi sehingga ia tidak salah dalam mengambil keputusan. Peran pendamping memberikan pertimbangan tetapi keputusan tetap ada di tangan orang yang di damping

b. Fungsi mendamaikan. Manusia adalah makluk sosial yang selalu berelasi dengan orang lain. Perbedaan individu dapat memecah konflik dalam relasi tersebut. Ketika ada dalam konflik manusia tidak dapat menyelesaikan sendiri. Kehadiran pendamping pastoral adalah untuk mendamaikan dan mengukuhkan relasi yang rusak.

c. Fungsi Menopang

Manusia menghadapi masalah yang menimbulkan emosi negatif seperti kematian, perceraian, kegagalan, musibah, wabah dan lain-lain. Berbagai peristiwa duka menyebabkan perasaan sedih, kecewa, putus asa, marah. Fungsi pendampingan adalah menopang dan menegakkan seseorang sehingga tidak terpuruk tapi bangkit dan menghadapi persoalan hidupnya.

d. Fungsi Menyembuhkan. Bagi mereka yang mengalami luka batin dan dukacita maka pendamping mengajak orang tersebut mengungkapkan perasaannya sehingga menciptakan keseimbangan yang baru, kemampuan mengembangkan fungsinya dalam kehidupan dan dinamis. e. Fungsi Mengasuh. Penolong hadir untuk menolong seseorang berkembang sesuai potensi dan kekuatannya. Penolong hadir untuk memelihara pertumbuhan emosional, pikiran, motivasi, kelakuan, interaksi, kehidupan rohani dan lain sebagainya.

f. Fungsi Mengutuhkan. Mengutuhkan adalah fungsi utama dari pendampingan pastoral. Dalam arti lewat pendampingan pastoral manusia mendapatkan pertolongan agar seluruh aspek kehidupannya baik fisik, sosial, mental dan spritual bertumbuh dan bersinergi sehingga menciptakan pertumbuhan manusia yang sejati.

\section{Tahapan Pendampingan Pastoral.}

Menurut Wiryasaputra (2003) ada 3 tahapan pendampingan Pastoral:

a. Tahapan awal: tahapan pertama dimana pendamping perlu menciptakan hubungan kepercayaan dengan orang yang di dampingi.

b. Tahapan tengah. Pada tahap ini pendamping melakukan 3 hal yaitu: anamnesis, sintesis dan diagnosa. Anamnesis artinya pendamping mengumpulkan data yang relevan, akurat dan menyeluruh berkaitan masalah. Sintesis artinya pendamping mencari kaitan antar gejala yang satu dengan gejala lain. Diagnosis adalah tahap pendamping melakukan analisis data yang relevan, akurat dan menyeluruh. Selanjutnya pendamping menarik kesimpulan masalah utama serta menyusun rencana aksi.

c. Tahap Akhir. Tindakan pertolongan dari pendamping terhadap yang didampingi secara berkesinambungan dan berkelanjutan. 


\section{Pendampingan Pastoral yang Holistik}

Holistik memiliki arti menyeluruh. Menurut Clinebell (dalam Singgih: 2004), pendampingan pastoral dan konseling yang holistik tidak hanya mengenai jiwa atau rohani tetapi juga keragaan. Pendekatan konseling yang holistik memperhatikan keseimbangan antara jasmani dan rohani. Pendekatan holistik terhadap penggembalaan memandang manusia sebagai makhluk yang memiliki kekayaan. Manusia dipahami dari sudut pandang positif. Kekayaan tersebut masih belum ditemukan. Kekayaan yang dimaksud adalah kekuatan, modal, potensi dan kemampuan menyelesaikan masalah. Pendampingan pastoral menolong manusia memunculkan kekuatannya untuk menyelesaikan masalah.

\section{Aspek Hidup Manusia Secara Holistik}

Menurut Wiryasaputra (2003) ada 3 aspek hidup manusia secara holistik:

1. Aspek fisik: aspek ini berkaitan dengan bagian yang terlihat dari diri manusia. Aspek fisik mengarah kepada apa yang dapat disentuh, dilihat dan diraba. Hal ini berkaitan pula dengan kebutuhan jasmani dari manusia. Bila dirinci maka aspek ini meliputi: pangan, papan, sandang, kebersihan tubuh, keutuhan tubuh, pelayanan medis, sistemik tubuh atau metabolisme tubuh, gerak badan, rileks-istirahat, dan lingkungan alam sekitar.

2. Aspek jiwa: aspek ini berkaitan dengan kepribadian seseorang seperti pikiran, emosi, dan perasaan seseorang. Hal ini berkaitan dengan rasa, motivasi, dan integrasi diri manusia. Rasa dalam pengertian ini adalah hubungan seseorang dengan bagian dalam dirinya yaitu batin dan jiwa. Aspek jiwa meliputi kasih sayang, kedewasaan emosional, integertas diri, kemampuan intelektual, kreativitas diri, identitas seksualitas, dan perasaan aman serta nyaman.

3. Aspek spiritual: berkaitan dengan citra diri manusia. Individu dapat berhubungan dengan sang pencipta sejati. Aspek ini meliputi, doa, kontemplasi, rasa manunggal bersekutu dengan sang mahakuasa, pengharapan akan masa depan, visi hidup, rasa bersyukur dan identifikasi komunitas 4. Aspek sosial meliputi: kondisi ekonomi yang memungkinkan seseorang hidup layak, kemampuan keuangan dan pekerjaan, kualitas pendidikan untuk menopang kehidupan, identifikasi kultural, kondisi adat istiadat dan hubungan dengan anggota keluarga, teman dan saudara,

Menurut Clinebell (2002) ada enam dimensi holistik manusia antara lain:

a. Dimensi menyegarkan pikiran artinya mengembangkan kemampuan personalitas yang kaya antara lain pemikiran, merasa, memimpikan dan menciptakan.

b. Dimensi membuat tubuh lebih bergairah. Aspek ini terkait dengan perhatian akan makanan bergizi, senam, kesegaran jasmani, pengurangan stres. Klien dituntun untuk mengasihi diri mereka sendiri.

c. Dimensi menolong orang dapat berupa memperbaharui dan memperkaya jaringan hubungan yang penuh rasa peduli. Penyembuhan dan pertumbuhan bergantung pada kualitas orang satu sama lainnya. Pendampingan pastoral memberikan latihan dan keterampilan untuk memperbaiki kualitas hubungan tersebut.

d. Dimensi memperdalam hubungan orang dengan alam dan lingkungan hidup. Orang akan utuh secara fisik, mental dan spiritual jika mereka ditolong mengembangkan dan menghargai interaksi yang sifatnya memelihara dengan alam.

e. Dimensi penyembuhan dan pertumbuhan lembaga sosial dan masyarakat. Pastoral seringkali bersifat sangat individualisme padahal masalah bisa berakar pada kondisi sosial (Rasisme, ketidakadilan, radikalisme). Seringkali masalah individu berakar pada masalah dalam masyarakat. 
Pendampingan pastoral memberikan pertumbuhan bagi individu sekaligus lembaga-lembaga sosial dan masyarakat.

f. Memperdalam dan menggairahkan hubungan dengan Allah. Pendampingan pastoral mengarah pada penguatan hubungan dengan Allah.

\section{Manfaat Pendampingan Pastoral Bagi Mahasiswa}

Berikut manfaat pendampingan pastoral bagi penyesuaian diri mahasiswa :

1. Sebagai seorang penolong dan pendengar bagi mahasiswa untuk bertahan dan menyesuaikan diri dengan perubahan pada lingkungan

2. Sebagai seorang penjaga. Cara ini digunakan agar mahasiswa merasakan bahwa ada yang mendukung atau menjaganya, sehingga mahasiswa tidak terlalu jauh tenggelam dalam kesedihan dan kesusahannya dalam menghadapi wabah ini.

3. Sebagai penyembuh (healing) dan pemulihan untuk mengatasi beberapa kerusakan dengan cara mengembalikan diri mahasiswa pada suatu keutuhan dan menuntun dirinya kearah yang lebih baik dari kondisi sebelumnya. Dengan dapat menerima keaadan dirinya maka klien akan dapat menerima penebusan dari Tuhan.

4. Sebagai seorang pendamping yang dapat memberikan penghiburan. Dengan memberikan penopangan, dukungan dan harapan bagi mahasiswa, itu berarti telah memberikan penghiburan.

Perhimpunan Dokter Paru Indonesia (PDPI) tahun 2020 menyatakan bahwa Coronavirus merupakan virus yang menyebabkan penyakit ringan sampai berat, seperti pilek, demam, menggigil dan penyakit yang serius yaitu MERS dan SARS. Di kota Wuhan Tiongkok tahun 2019 virus corona pertama kali ditemukan. Proses penyebaran dari hewan ke manusia (zoonosis) dan dapat melalui interaksi antara manusia dengan manusia. Proses penyebaran sangatlah cepat. Berbagai gejala seperti demam, batuk, sesak nafas sehingga membutuhkan perawatan Rumah Sakit (RS). Gejala ini diperberat jika penderita adalah usia lanjut dan mempunyai penyakit kronis yang menyertai seperti penyakit paru, diabetes, dan penyakit jantung.

Kemenkes menerbitkan Surat Edaran kepada seluruh Dinas Kesehatan Provinsi dan Kab/Kota, RS Rujukan, Kantor Kesehatan Pelabuhan (KKP) dan Balai Teknik Kesehatan Lingkungan (BTKL) untuk meningkatkan kewaspadaan dan kesiapsiagaan dalam menghadapi kemungkinan masuknya penyakit ini. Langkah ini sebagai bagian dari upaya Pemerintah Indonesia dalam menangani kasus Covid-19. Pemerintah juga memberlakukan work from home (WFH) kepada masyarakat Indonesia dengan tidak berpergian keluar rumah dalam rentangan waktu yang cukup lama.

Selain itu pemerintah meningkatkan kewaspadaan dan kesiapsiagaan di pintu masuk Negara seperti di bandara, pelabuhan maupun lintas batas darat negara. Pemerintah Indonesia melakukan himbauan agar masyarakat tidak panik dan tetap waspada. Upaya tersebut seperti dengan sering mencuci tangan dengan sabun atau cairan pembersih tangan mengandung alkohol, menghindari kontak dengan orang yang sedang sakit. Jika mengalami gejala demam dan gangguan pernapasan dapat menghindar dengan cara tidak keluar rumah kecuali untuk berobat, gunakan masker dan menerapkan etika bersin/batuk. Serta bila gejalanya muncul saat sudah kembali ke tanah air, agar segera berobat dan menyampaikan riwayat perjalanannya kepada dokter. 


\section{Sampel Sumber Data}

Informan dalam penelitian ini yakni mahasiswa IAKN Kupang sejumlah 10 yang berusia 18-25 tahun. Kesepuluh mahasiswa tersebut terdiri dari: 4 mahasiswa jurusan Pendidikan Agama Kristen, 3 mahasiswa jurusan Pastoral Konseling dan 3 mahasiswa jurusan Musik Gerejawi.

Data Responden

\begin{tabular}{|c|c|c|c|c|c|c|}
\hline No & $\begin{array}{c}\text { Nama } \\
\text { (Inisial) }\end{array}$ & $\begin{array}{c}\text { Jenis } \\
\text { Kelamin }\end{array}$ & Umur & $\begin{array}{c}\text { Jurusan/Se } \\
\text { mester }\end{array}$ & Status & Ket \\
\hline 1 & MO & $\mathrm{P}$ & 19 tahun & Muger/2 & Belum menikah & - \\
\hline 2 & $\mathrm{SO}$ & $\mathrm{P}$ & 19 tahun & Muger/2 & Belum menikah & - \\
\hline 3 & $\mathrm{JL}$ & $\mathrm{L}$ & 19 tahun & Muger/2 & Belum menikah & - \\
\hline 4 & $\mathrm{MN}$ & $\mathrm{L}$ & 25 tahun & $\mathrm{PK} / 6$ & Belum menikah & - \\
\hline 5 & $\mathrm{ES}$ & $\mathrm{P}$ & 23 tahun & $\mathrm{PK} / 6$ & Belum menikah & - \\
\hline 6 & $\mathrm{RM}$ & $\mathrm{P}$ & 23 tahun & $\mathrm{PK} / 6$ & Belum menikah & - \\
\hline 7 & $\mathrm{JO}$ & $\mathrm{P}$ & 19 tahun & $\mathrm{PAK} / 2$ & Belum menikah & - \\
\hline 8 & $\mathrm{MN}$ & $\mathrm{P}$ & 19 tahun & PAK/2 & Belum menikah & - \\
\hline 9 & $\mathrm{IM}$ & $\mathrm{L}$ & 20 tahun & PAK/2 & Belum Menikah & - \\
\hline 10 & $\mathrm{YE}$ & $\mathrm{L}$ & 22 tahun & PAK/2 & Belum menikah & - \\
\hline
\end{tabular}

Berdasarkan hasil penelitian diperoleh data pemahaman mahasiswa tentang covid 19 adalah sebanyak 9 orang adalah penyakit yang disebabkan oleh virus yang menular dan mematikan, sedangkan 1 mahasiswa berpendapat covid 19 disebabkan oleh bakteri yang menyebar sangat cepat sehingga perlu ditakuti. Virus ini berasal Wuhan-China dan dapat menyebabkan kematian dalam waktu singkat. Ada mahasiswa yang menyatakan penyakit kronis artinya sangat berbahaya. Virus ini juga tidak kenal usia sebab lebih rentan menyerang lansia dan anak-anak. Pendapat lain dari mahasiswa bahwa Covid 19 juga dipahami sebagai teguran Tuhan agar manusia bisa menjaga kesehatan dan mengatur waktu bersama keluarga. Ada dugaan virus ini buatan manusia untuk tujuan bisnis yakni penjualan aplikasi demi keuntungan pihak tertentu.

Berdasarkan hasil wawancara diperoleh data mahasiswa narasumber memperoleh informasi tentang covid 19 dari media sosial seperti facebook dan whatsup, media online: google, media elektronik yaitu televise dan radio, keluarga, dosen pembimbing akademik, dosen pengajar, teman kuliah dan gereja.

Hasil wawancara kepada sepuluh subjek mengatakan bahwa merasa sehat dan tidak mengidap penyakit selama masa pandemi Covid-19. Sepuluh mahasiswa dari tiga program studi ini menyatakan bahwa tetap menjaga kesehatan selama masa pandemi dengan cara mematuhi aturan protokol pemerintah yaitu memakai masker, rajin cuci tangan dengan air mengalir dan sabun, selalu membawa handsanitizer, serta menjaga jarak ketika bertemu. Berikut pernyataan yang dikatakan oleh mahasiswa :

"Cara saya menjaga kesehatan adalah menjaga jarak dengan orang lain, rajin cuci tangan saat selesai berpergian, dan tidak lupa menggunakan masker saat berpergian keluar rumah bu (JO, 19 tahun).

Selain mengikuti himbauan pemerintah, mahasiswa juga menjaga fisik dan kesehatan dengan cara berolahraga, rajin mandi, mengkonsumsi vitamin, dan menjaga pola makan. Hal tersebut sesuai dengan hasil wawancara dengan ke dua mahasiswa di bawah ini : 
Mengatur pola makan yang baik, istirahat yang cukup dan berolah raga, menggunakan masker jika berkativitas di luar, rajin mandi dan cuci tangan (IM, 20 tahun).

Dengan mematuhi aturan pemerintah bahwa, selama masa pandemi ini setiap masyarakat tinggal di rumah selama 14 hari untuk menghindari covid 19. Saya juga menjaga makanan yang saya makan (JL, 19 tahun).

Mahasiswa melakukan beberapa pencegahan di atas karena menyadari bahwa Covid-19 sangat membahayakan kesehatan. Sehingga mahasiswa berinisiatif untuk rajin berolahrga, makan makanan yang bergizi, mengkonsumsi vitamin, dan istirahat yang cukup. Dengan demikian diketahui bahwa kesepuluh mahasiswa di 3 Prodi IAKN Kupang dalam keadaan fisik yang sehat selama masa pandemi Covid-19. Ketika diwawancarai pun, mahasiswa Musik Gerejawi datang ke ruangan dengan terlebih dahulu mencuci tangannya, memakai masker ketika di wawancarai, serta menjaga jarak tempat duduk.

Permasalahan sosial dialami oleh kesepuluh mahasiswa yang diwawancarai. Masalah yang sering muncul adalah terkait ekonomi. Covid-19 yang terjadi membuat perekonomian orangtua mahasiswa menjadi terhambat. Khususnya orangtua yang berprofesi sebaga petani. Gagal panen yang dirasakan membuat pengiriman uang kepada mahasiswa menjadi terhambat. Mahasiswa pun kesulitan dalam hal konsumsi dan membeli paket internet untuk proses perkuliahan.

Kendala yang di alami selama di tengah wabah covid 19, ini biaya hidup yang sangat minim. Orangtua telat mengirimkan uang sehingga bahan pangan tidak ada (JL, 19 tahun).

Sering terlambat bayar uang kos karena orangtua belum dapat uang. Menghadapi masalah ekonomi kekurangan makan dan minum karena di kampung pasar desa tutup sehingga orangtua tidak dapat menjual hasil kebun serta kesulitan isi paket data (IM, 20 tahun).

Permasalahan lain yang muncul adalah pemahaman mahasiswa terkait pembelajaran dengan menggunakan media online seperti zoom, grup whatsapp, dan google classroom.

Belajar menggunakan aplikasi baru. Respon saya belajar menggunakan aplikasi tersebut dengan bertanya pada teman. Saat ini saya sudah dapat menggunakan aplikasi yang digunakan para dosen dan saya berpikir pengetahuan baru yang saya peroleh berguna bagi diri dan pekerjaan saya

merasa bingung dengan cara menggunakan berbagai aplikasi yang digunakan dosen seperti zoom, grup whatsup, dan google classroom. Aplikasi ini baru bagi mahasiswa (YE, 22 tahun).

Berdasarkan hasil wawancara didapatkan bahwa kesepuluh mahasiswa mengalami kesulitan dalam menjalani perubahan tata cara beribadah. Selain karena kesulitan membeli paket internet untuk mengikuti ibadah online, mahasiswa juga merasa bahwa tidak khusyuk dan hikmat dalam beribadah. 
Kurang mampu untuk konsentrasi. Saat Ibadah sedang berlangsung saya kadang minum ataupun makan dan jika sibuk saya sudah lupa ibadah (JO, 19 tahun).

Untuk ibadah minggu subjek kadang beribadah dari kos hanya jam tidak sesuai jadwal gereja dan kadang tidak karena ketiduran (IM, 20 tahun).

Saya jarang ibadah dari rumah karena terus tidur walaupun mendengar lonceng gereja berbunyi. Saya juga sering lupa jam dan jadwal ibadah (YE, 22 tahun).

Masalah psikologis dirasakan oleh kesepuluh mahasiswa IAKN Kupang. Perasaan cemas, takut dan khawatir menjadi masalah psikologis yang terjadi. Beberapa mahasiswa seperti menyatakan bahwa tetap mencoba tenang dengan mematuhi protokol kesehatan, bahkan tetap mengandalkan Tuhan dengan selalu berdoa dan beribadah. Mahasiswa merasa takut dan khawatir karena mengetahui bahwa Covid-19 adalah penyakit berbahaya yang menular, sehingga adanya perasaan cemas bila terinfeksi. Berikut penggalan hasil wawancara yang menunjukkan keadaan psikologis mahasiswa :

"Penyakit yang disebabkan oleh virus yang cepat sekali menyebarnya, sehingga perlu ditakuti. Karena bisa berakibat kematian. Terutama yang memiliki penyakit turunan seperti diabetes dan jantung (JL, 19 tahun).

Iya saya cemas, kuatir dan takut karena tiap hari ada peningkatan jumlah orang yang terinfeksi covid-19. Jumlah pasien sembuh memang meningkat tetapi jumlah yang meninggal juga meningkat (IM, 20 tahun).

Selain perasaan yang disebutkan di atas, masalah yang muncul adalah perubahan proses pembelajaran. Sehingga mahasiswa YE (22 tahun) merasa marah dan bingung kepada dosen karena perubahan cara dan jadwal mengajar. Perasaan kesal juga dialami oleh mahasiswa terhadap rekan mahasiswa yang dianggap seenaknya menjiplak tugas kuliah miliknya. JO (19 tahun) merasa tidak tidak bisa menoleransi perilaku temannya yang menjiplak dengan alasan tidak mempunyai paket data untuk mengerjakan tugas.

Marah karena ada dosen memberi kuliah tidak sesuai jadwal. Kadang ada 2 dosen memberi kuliah bersamaan sehingga mahasiswa bingung mau mengikuti perkuliahan yang mana. Mahasiswa tidak berani memberi tahu karena takut dimarahi dosen. Subjek mengaku kadang memberi tahu dosen kadang tidak (YE, 22 tahun).

Merasa jengkel karena ada teman yang suka copy paste tugas hasil kerja saya. Saya berpikir sudah capek kerja sendiri tapi teman dengan segala alasan hanya minta copy paste agar bisa dapat nilai (JO, 19 tahun).

Salah satu permasalahan psikologis yang dialami mahasiswa JO (19 tahun) adalah perasaan kesepian karena tidak mampu bertemu dengan teman-temannya di kampus. kesepian karena biasa berkumpul dengan teman-teman kuliah sedangkan pada saat wabah sulit bertemu karena tidak ke kampus (JO, 19 tahun).

Reaksi dari perasaan cemas, takut, khawatir, dan kesepian yang dirasakan mahasiswa pun berbeda-beda terutama ketika berada di tempat umum. Reaksi fisik seperti jantung berdegup kencang, gugup, dan keringatan bahkan deg-degan ketika melakukan aktivitas yang biasa di 
lakukan. Mahasiswa yang berolahraga pun untuk menjaga kesehatan merasa tetap harus waspada dengan menyebarnya Covid-19.

Saya pusing dan deg-degan bu. Makanya saya banyak minum air putih biar tidak keringatan. Terlebih melihat teman yang tidak gunakan masker (JL, 19 tahun).

Jantung saya kayak degup kencang lihat kerumunan orang di tempat foto kopi. Biasanya tangan saya juga basah karena keringatan dan cemas (SO, 19 tahun).

Saya gugup bila bertemu dengan kerumunan orang. Saya kan berusaha olahraga karena biasanya begitu. Lari sore bu. Tapi gugup begitu saat lari sore. Jadi tidak berani lama-lama (M0, 19 tahun).

Berdasarkan hasil penelitian diperoleh hasil subjek menghadapi berbagai perubahan hidup selama covid 19 dan subjek mampu menghadapi masalah yang muncul akibat covid 19 karena memiliki motivasi dalam dirinya sendiri yang mendorong mahasiwa melakukan penyesuain diri dan upaya menyelesaikan masalah tersebut. Motivasi Internal dalam penelitian ini berkaitan dengan hal pendidikan dan kesehatan. Sekalipun memiliki motivasi internal yang kuat, seluruh subjek mengaku lebih senang perkuliahan tatap muka ataupun ibadah non online karena menurut penilaian subjek lebih efektif.

Subjek JL, AT, MN, IM dan YE memiliki semangat kuliah online walaupun kesulitan biaya membeli paket data dan lemahnya sinyal internet. AT mengaku semangatnya muncul karena ia ingin meraih cita-citanya sedangkan JL, MN, IM dan YE mengalami perasaan tidak aman, cemas atau dalam dirinya terkait nilai yang rendah dan ia tidak lulus kuliah jika tidak berusaha ikut kuliah daring. Rasa tidak aman yang muncul dari pemikiran demikian mendorong subjek berhemat sehingga bisa membeli paket data dan ikut kuliah online. Subjek mengaku kiriman orangtua minim sempat membuat mereka cemas dan takut. Subjek mengaku terkadang tidak bisa mengikuti kuliah jika tidak punya paket.

Bagi AT dan JO penggunaan aplikasi online dalam perkuliahan daring membuat mereka senang karena walaupun awalnya harus kesulitan mempelajari berbagai aplikasi seperti zoom, google classroom dll namun mereka sadar penguasaang aplikasi belajar yang baru akan menunjang profesi mereka ke depan saat menjadi pengajar.

Seluruh subjek mengaku melakukan perubahan hidup karena ada keinginan dalam diri ingin sehat dan terhindar dari bahaya covid 19. Mereka sadar covid 19 adalah penyakit menular dan mematikan. Subjek tidak ingin berpisah dari keluarga akibat korona. Mereka mengaku sadar pasien corona yang sudah terbukti lewat rapid test ataupun tes swab akan diisolasi pihak rumah sakit sehingga pasien tidak dapat bertemu dengan keluarga. Jika pasien meninggal mereka tidak bisa dikuburkan keluarga melainkan pihak rumah sakit. Para subjek mengaku menerapkan protokol penerintah antara lain: tidak keluar rumah, cuci tangan, pakai masker dan lain-lain.

Berdasarkan hasil penelitian diperoleh data subjek mampu menghadapi masalah yang muncul sebagai dampak wabah covid 19 karena adanya motivasi eksternal atau daya dukung dari luar. Para subjek mengaku tidak senang, cemas dan jengkel menghadapi perubahan akibat covid 19. Daya dukung yang dimaksud antara lain orangtua, teman, gereja dan pemerintah dan faktor lainnya. Daya dukung eksternal yang diterima bervariasi diantara para subjek. Dukungan dari luar terbukti membuat mereka kuat serta mampu mengatasi berbagai masalah yang muncul akibat wabah covid 19. Dukungan dari luar berupa nasihat, saran, bantuan keuangan dan tuntunan penggunaan aplikasi belajar online. Dukungan dari luar juga terbukti menimbulkan emosi positif berupa perasaan senang. 
Dari hasil wawancara diperoleh hasil subjek SO, MO, berjuang kuliah online karena mereka mendapat beasiswa sehingga mereka harus berusaha memperoleh nilai yang baik agar tidak kehilangan beasiswa dari kampus.

Data penelitian menunjukkan ada subjek yang mendapat dukungan dari orangtua namun ada juga yang tidak mendapatkan dukungan dari orangtua namun mereka mendapatkan dukungan dari Paman atau teman. Subjek SO, MO tidak dapat dukungan dari orangtua berupa nasihat, arahan atau dana yang cukup. Mereka berusaha sendiri untuk mengatasi masalahnya. Walaupun demikian ada pihak lain yakni ibu pemilik kos SO yang memberi dukungan kepadanya dalam hal Ibadah. Ia mengaku biasa beribadah secara online dengan menggunakan paket data dan handphone milik Ibu Kos melalui channel youtube sehingga tidak pelu mengeluarkan untuk ibadah online. Subjek MO mendapatkan dukungan dari keluarga yakni paman dan kakak sepupu. Dukungan yang diperoleh berupa motivasi agar semangat ikut kuliah online sedangkan bentuk dukungan dari kakak sepupu adalah mengajari cara mengirim tugas menggunakan aplikasi yang diminta dosen pengajar. Subjek AT mendapatkan pendampingan dari pemilik kos berupa motivasi dan pengayoman serta bantuan sembako dan uang.

Subjek JL,MN, IM dan YE mengaku mendapat dukungan dari keluarga terdekat khususnya orangtua berupa kiriman uang dan perhatian. Orangtua mengingatkan agar mereka menjaga kesehatan dengan menjaga pola makan, beristirahat, rajin mencuci tangan. menggunakan masker dan keluar rumah hanya jika ada urusan penting saja. Selain dari orangtua, JL juga mendapat dukungan dari anggota keluarga lainnya berupa motivasi agar tidak takut, gelisah dan tidak menyerah menghadapi kuliah online. JL mengaku orangtua sering melakukan video call sehingga mereka selalu beriadah bersama walaupun subjek mengakui tidak konsetrasi beribadah secara online.

Hasil penelitian menunjukkan ada subjek yang mendapatkan dukungan dari teman tetapi ada juga yang tidak. Subjek JO mengaku mengaku mendapat bimbingan dan pendampingan dari temannya selama wabah covid 19. Ia tidak pulang ke rumah melainkan memilih tetap berada di Kupang sehari-hari. Dukungan dari teman berupa kesediaan mendengar segala keluh kesah subjek dan nasihat kepadanya untuk melakukan berbagai perubahan sehingga tidak terpapar corona. Subjek SO, JO dan MN mendapat dukungan dari teman yakni diberi makan sesekali oleh teman karena kiriman orangtua minim. Dalam keadaan terpaksa mereka makan hanya sekali sehari. Sedangan subjek JL, AT, MN dan IM mendapat dukungan teman berupa dorongan semangat meraih apa yang dicita-citakan bersama, bantuan jika kesulitan memahami materi atau aplikasi yang digunakan selama perkuliahan online.

Ada subjek yang mendapatkan dukungan dari pemerintah tetapi ada juga yang tidak. Subjek SO, MO, JL, MN dan IM mengaku tidak pernah mendapatkan bantuan dari pemerintah sedangkan subjek AT mengaku mendapatkan bantuan sembako dari pemerintah. Bantuan tersebut meringankan beban ekonomi yang dialami sebagai dampak wabah covid 19. Subjek YE mengaku mendapat dukungan pemerintah berupa nasihat dan himbauan agar ia dapat menjaga kesehatan dengan baik.

Ada subjek yang mendapatkan dukungan dari kampus tetapi ada juga yang tidak. Subjek SO, MO, AT dan JL mengaku tidak mendapatkan bantuan dari kampus walaupun ada program bantuan sembako sedangkan IM dan YE mengaku mendapat bantuan sembako dari kampus. IM dan YE juga mendapat dukungan dari kampus lewat dosen PA dan dosen pengajar yang selalu mengingatkan agar mereka berhati-hati dan menjaga kesehatan.

Semua subjek tidak mendapat bantuan dari gereja baik pendampingan maupun sembako walaupun mereka tahu ada sumbangan yang diberikan kepada jemaat. Secara khusus IM mengaku mendapat dukungan dari gereja berupa himbauan beribadah dari rumah untuk mencegah penularan 
covid 19. Subjek YE mengaku mendapat ukungan dari gereja berupa pewartaan injil secara online lewat aplikasi youtube.

Berdasarkan hasil penelitian maka pada bagian ini peneliti akan membahas temuan tersebut dengan mengacu pada fokus penelitian yaitu pada penyesuaian diri mahasiswa IAKN Kupang terhadap Covid-19.

\section{Penyesuaian Diri Mahasiswa IAKN terhadap Covid-19}

Pada aspek penyesuaian diri pribadi, kesepuluh mahasiswa cukup mampu menyesuaikan dalam hal menerapkan protokol kesehatan yang diterapkan Pemerintah. Kesepuluh mahasiswa mampu untuk menjaga jarak ketika di kampus dan tempat umum, memakai masker, seringnya mencuci tangan, dan menjaga kebersihan. Selain itu dari segi fisik, mahasiswa merasa sehat dengan tetap menjaga pola makan dan olahraga. Di sisi lain, mahasiswa merasakan ketidaknyamanan untuk beberapa hal seperti keterbatasan uang dan makanan yang diberikan orangtua akibat dampak Covid-19, penyesuaian diri terhadap proses pembelajaran berbasis online, ibadah online, dan perasaan-perasaan cemas karena kurangnya pengetahuan mahasiswa akan Covid-19.

Pengetahuan mahasiswa akan bahaya Covid-19 pun masih minim. Adanya mengatakan bahwa Covid-19 adalah bakteri, ada pula yang mengatakan berupa virus. Mahasiswa beranggapan bahwa Covid-19 adalah penyakit menular yang mematikan. Pengetahuan ini mahasiswa ketahui dari media sosial dan surat kabar. Sebagai individu, mahasiswa harus mampu bertindak obyektif sesuai dengan kondisi yang terjadi di masyarakat (Buchori, 2002). Mahasiswa mampu menyaring informasi yang didapat dengan baik, sehingga cukup mampu menerapkan protokol kesehatan yang diterapkan pemerintah. Namun, ada pula mahasiswa yang merasa cemas akan terinfeksi Covid-19 sehingga terkadang merasa deg-degan dan keringatan bila di tempat umum. Ketakutan tersebut dikarenakan melihat dan mendengar jumlah kematian yang terus bertambah akibat Covid-19.

Mahasiswa mengalami keterbatasan dalam hal ekonomi khususnya uang makan, uang kos, dan biaya internet yang telat diberikan oleh orangtua. Orangtua mahasiswa yang sebagaian besar adalah petani mengalami gagal panen yang berakibat pada kurangnya pemasukan. Adanya keterbatasan tersebut berdampak pada makanan yang dikonsumsi sehari-hari. Setiap harinya mahasiswa harus irit dalam membeli bahan makanan. Berbeda dengan mahasiswa yang tinggal bersama wali atau orangtua yang masih terjamin akan ketersediaan makanan.

Mahasiswa juga mengalami kendala dalam perkuliahan online. Mahasiswa harus berupanya untuk belajar dan memahami proses perkuliahan online yang baru diterapkan. Begitu pula dengan ibadah online setiap minggu. Mahasiswa mengakui kurang mampu untuk bisa merasa tenang, khusyuk, dan hikmat selama ibadah berlangsung. Mahasiswa mudah teralihkan pikirannya selama ibadah. Perbedaan yang mencolok antara sebelum dan sesudah Covid-19 ini membuat mahasiswa malas dan enggan untuk mengikuti perkuliahan dan ibadah online. Mahasiswa pun mengkhawatirkan nilai mereka semester ini, terlebih seringnya teman yang hanya mengjiplak tugas mereka untuk dikumpulkan. Adanya perasaan tidak adil, namun karena keterbatasan membuat mereka untuk mau saling berbagi.

Aspek yang kedua yaitu penyesuaian sosial mahasiswa. Ruang lingkup penyesuaian sosial dapat terjadi dimana individu beriteraksi dengan orang lain dan hubungan dirinya dengan masyarakat sekitar. Setiap individu dapat saling memengaruhi satu sama lain yang mempunyai aturan, hukum, adat, dan nilai-nilai yang dipatuhi (Buchori, 2002). Adanya Covid-19 sangat dirasakan mahasiswa IAKN Kupang. Mahasiswa yang sering berkumpul bersama teman-teman merasa sangat dibatasi ruang geraknya. Terlebih lagi mahasiswa yang kebanyakan adalah anak kos. Mereka hanya bisa berdiam diri tanpa mampu melakukan aktivitas di luar rumah. Hal ini sesuai dengan penyesuaian diri sosial, dimana dalam penyesuaian sosial individu dituntut mematuhi 
norma dan peraturan sosial di masyarakat. Mahasiswa diminta tetap mematuhi kebijakan yang diterapkan akibat Covid-19.

Penyesuaian sosial juga terjadi dalam keluarga mahasiswa. Covid-19 membatasi mahasiswa untuk pulang kembali ke kampong halaman. Hal ini dikarenakan kota Kupang masuk pada zona yang terindikasi terpapar Covid-19. Oleh karena itu, beberapa mahasiswa hanya bisa berdiam diri di dalam kos. Terbatasnya ruang gerak mahasiswa membuat mereka merasa bosan dan jenuh. Keadaan ini membuat mahasiswa terkadang ingin untuk pergi ke tempat umum, misalnya untuk mengfotocopy bahan ajar atau berolahraga agar tetap menjaga kesehatan diri.

\section{Peran Pendampingan Pastoral Pada Mahasiswa}

Selama masa pandemi Covid-19, beberapa mahasiswa mendapatkan dukungan langsung dari orangtua. Ada pula yang merasa mendapatkan pendampingan dari paman dan ibu kosnya. Pendampingan adalah kegiatan saling tolong menolong, menemani, saling berbagi, sehingga dapat saling menumbuhkan dan mengutuhkan (Bebek, 2014). Pendampingan yang diberikan tentunya bersifat holistik. Menurut Clinebell (dalam Singgih, 2004) pendampingan pastoral dan konseling yang holistik tidak hanya mengenai jiwa atau rohani tetapi juga keragaan. Pendekatan konseling yang holistik memperhatikan keseimbangan antara jasmani dan rohani. Oleh karena itu pendampingan yang diterima mahasiswa tidak hanya berupa nasihat dan saran namun juga berupa dana.

Pendampingan yang diberikan orang-orang yang ada disekitar mahasiswa berupa nasihat dan saran untuk hidup sehat, mematuhi protokol kesehatan, dan tetap bersemangat dalam menjalani perkuliahan online. Orangtua dan pendamping dapat sebagai seorang penolong dan pendengar bagi mahasiswa untuk bertahan dan melewati suatu keadaan yang di alaminya, khususnya di saat pandemi Covid-19. Selain itu sebagai seorang pendamping yang dapat memberikan penghiburan. Dengan memberikan penopangan, dukungan dan harapan bagi mahasiswa, itu berarti telah memberikan penghiburan.

Dukungan secara ekonomi juga dirasakan oleh mahasiswa yang mendapatkan bantuan sembako dari IAKN Kupang dan pihak gereja. Beberapa bantuan yang didapat mahasiswa tersebut dapat meringankan beban khususnya dalam hal pangan dan alat kesehatan. Mahasiswa diberikan sembako dan alat kesehatan seperti masker dan handsanitizer. Bantuan yang diberikan dapat memenuhi aspek fisik yang berkaitan dengan bagian yang tampak dari hidup manusia. Aspek fisik mengarah kepada apa yang dapat disentuh, dilihat dan diraba oleh manusia. Hal ini berkaitan dengan kebutuhan jasmani dari manusia. Bila dirinci maka aspek ini meliputi: makan, minum, pakaian, kebersihan tubuh, keutuhan tubuh, pelayanan medis, gerakan badan, waktu istrirahat dan lingkungan alam disekitar manusia (Wiryasaputra, 2003).

Pendampingan rohani secara ekonomi dapat diberikan seperti Ibu kos bersama-sama dengan subjek untuk mengikuti ibadah online, sehingga dapat mengurangi beban subjek dalam membeli paket internet. Meskipun seperti itu, masih saja ada mahasiswa yang kurang dalam segi rohani, dimana mahasiswa mengikuti ibadah online tidak secara total. Mahasiswa masih enggan fokus ketika ibadah, melakukan aktivitas lain saat ibadah, bahkan tidak mengikuti ibadah karena tidur. Alasan mahasiswa adalah karena merasa tidak khusyuk dan hikmat dalam mengikuti ibadah online. Sehingga pentingnya peran orang-orang terdekat untuk tetap memberikan penguatan dan motivasi pada mahasiswa dalam menjalankan ibadah secara online. 


\section{KESIMPULAN}

Hasil penelitian yang telah dilakukan mengenai Pendampingan Pastoral Terhadap Penyesuaian Diri Mahasiswa IAKN Kupang Dalam Menghadapi Pandemi Covid-19 adalah bahwa kesepuluh mahasiswa cukup mampu menyesuaikan diri dalam hal menerapkan protokol kesehatan yang diterapkan Pemerintah. Hal tersebut tidaklah lepas dari peran orangtua, kampus, gereja, dan pemerintahan sebagai pendamping.

Selain itu sebagai seorang pendamping yang dapat memberikan penghiburan. Dengan memberikan penopangan, dukungan dan harapan bagi mahasiswa, itu berarti telah memberikan penghiburan. Dukungan secara ekonomi juga dirasakan oleh mahasiswa yang mendapatkan bantuan sembako dari IAKN Kupang dan pihak gereja. Beberapa bantuan yang didapat mahasiswa tersebut dapat meringankan beban khususnya dalam hal pangan dan alat kesehatan. Dengan adanya pendampingan mampu menolong mahasiswa dari segi fisik, psikis, sosial, dan spiritual.

Pihak kampus perlu membentuk tim pendampingan bagi mahasiswa. Sehingga pendampingan yang diberikan lebih fokus dan secara menyeluruh. Dengan adanya pendampingan yang dilakukan oleh dosen diharapkan permasalahan-permasalahan yang dialami mahasiswa dapat mudah ditangani, terkhususnya masalah dalam proses pembelajaran online.

Bersama dengan gereja dapat bekerja sama dengan pihak kampus untuk memberikan pendampingan spiritual, sehingga mahasiswa mendapatkan pembinaan secara khusus dari ahlinya. Dengan adanya pembinaan ini diharapkan mahasiswa dapat melalui masa pandemi dengan baik.

Bersama dengan Pemerintah daerah secara berkala memberikan bantuan berupa sembako dan APD bagi mahasiswa, sehingga mahasiswa tetap mampu bertahan dalam masa pandemi Covid 19 . 


\section{DAFTAR PUSTAKA}

Abineno, Dr. J. L. Ch. Pedoman Praktis untuk Pelayanan Pastoral. 2006. Jakarta: BPK gunung mulia.

Agustiani, 2006. Psikologi Perkembangan : Pendekatan Ekologi Kaitannya dengan Konsep Diri dengan Penyesuaian Diri Pada Remaja. Bandung: PT Refika Aditama

Ali, M dan Asrori, M. 2005. Psikologi Remaja Perkembangan Peserta Didik. Jakarta: PT Bumi Aksara

Bambang Mulyono. Y. 1993. Mengatasi Kenakalan Remaja. Yogyakarta: Yayasan Andi

Beek, AAR Van. Pendampingan Pastoral. 2007. Jakarta: BPK Gunung Mulia. Pendampingan Pastoral. 2015. Jakarta: BPK Gunung Mulia

Bons-Storm, Prof.dr. 2012. Apakah Penggembalaan Itu. Jakarta: BPK gunung Mulia.

Diane E. Papalia, et. Al. (2008). Human Development (Psikologi Perkembangan). Jakarta. Fatimah, 2006. Psikologi Perkembangan. Bandung: CV Pusaka Setia

Gunarsa, S. D, \& Gunarsa, Y. S. D. 2001. Psikologi Perkembangan Anak dan Remaja. Jakarta: BPK Gunung Mulia.

Hurlock, E. B. (2004). Psikologi perkembangan suatu pendekatan sepanjang rentang kehidupan. Edisi Kelima. Jakarta: PT. Erlangga.

Jalaluddin. R. 2007. Psikologi agama: Memahami perilaku keagamaan dengan mengaplikasikan prinsip-prinsip psikologi. Jakarta: PT Rajagrafindo Persada

KBBI, 2016. Kamus Besar Bahasa Indonesia (KBBI). [Online] Available at: http://kbbi.web.id/pusat, [Diakses 25 April 2020].

Perhimpuan Dokter Paru Indonesia. (2020). Panduan Praktik Klinis : Pneumonia 2019nCoV.PDPI:Jakarta

Santrock, J. W. (2011). Life-span development: Perkembangan masa hidup, edisi tigabelas, jilid 1. Alih bahasa: Benedictine Widyasinta. Jakarta: Erlangga.

Sarlito Wirawan Sarwono dan Amisiamsidar. 1986. Peranan Orang Tua dalam Pendidikan Seks. Jakarta: Rajawali.

Semiun, Y. (2006). Kesehatan mental 1; pandangan umum mengenai penyesuaian diri dan kesehatan mental serta teori-teori yang terkait. Yogyakarta: Kanisius.

Singgih, Emanuel Gerrit Ph.d. 2004. Mengantisipasi Masa Depan Berteologi dalam Konteks di Awal Millenium III. Jakarta: Bpk Gunung Mulia.

Siswoyo. Dkk. (2007). Ilmu Pendidikan. Yogyakarta: UNY Press 
Sunarto \& Hartono, Agung. 2013. Perkembangan Peserta Didik. Jakarta : Rineka Cipta Sugiyono. 2014. Metode Penelitian Kualitatif dan R \&D. Bandung: Alfabeta

Wirya Saputra, Totok. S. 2003.Mengapa Berduka Kreatif Mengelola Perasaan Berduka. Jogjakarta: Kanisius

WHO. (2020). WHO Director-Generals remarks at the media briefing on 2019-nCoV on 11 February 2020. Cited Feb 13rd 2020. Available on : https://www.who.int/dg/speeches/detail/who-director-generals-remarks-at-themedia-briefing-on-2019-ncov-on-11-february-2020.(Feb 12 $2^{\text {th }} 2020$ ). 